\title{
The Inextricable Nexus between Poverty and Politicians in Africa
}

\author{
Dr. Ambrues Monboe Nebo Sr. \\ (Doctor of Sociology D.Sc), Department of Political Science, University of Liberia
}

\begin{abstract}
Researchers have documented multiple causes that explain the reasons for the persistence of extreme poverty in Africa, despite existence of comprehensive policy frameworks (Poverty Reduction Strategy). These causes are: corruption and poor governance, limited employment opportunities, poor infrastructure, poor resource usage, wars and unending conflicts, poor World Bank and IMF policies, among others. While sustaining these genuine causes, this paper probably the first of its kind look at different reason that explains the persistence of extreme poverty in Africa. It looks at the inextricable nexus between poverty and politicians as another reason for extreme poverty, especially in Sub-Saharan Africa. This article argues that the existence of extreme poverty is strategic to the political agenda and promotion of politicians. In other words, this paper makes the case that extreme poverty protects and enhances the selfish interests of politicians. And because poverty serves the personal interest of politicians, the urge and inclination to substantially reduce poverty have remained a mere lip political rhetoric in Africa. Precisely, the paper advances the argument that vote buying is the interest that explains the nexus between the former and the latter in Africa.
\end{abstract}

To solve this old aged problem, this article recommend that civil society must rollout their sleeves to robustly engage electorates through the concept of sustain civic education for holding politicians accountable for their failures or pretense of reducing extreme poverty substantially.

Key Words: Poverty, Politician, Poverty Reduction Strategy, Vote buying,

\section{INTRODUCTION}

$\mathrm{O}$ ver the past two decades, Politicians in Africa as fulfillment of campaign manifestos or promises have introduced a good number of comprehensive policy frameworks intended to tackle or reduce the prevalence of extreme poverty. This ambitious framework is called poverty reduction strategies. For example, in 1997, Uganda's government launched its Poverty Eradication Action Plan (PEAP) with subsequent revisions in 2000 and 2005 (Canagarajah, A van Diesen, 2006)

In 2009, Liberia's government launched its poverty reduction strategy (VOA, 2009). The Kenyan government committed itself to poverty alleviation by 2015 through the adoption of the National Poverty Eradication Plan (Nyamboga, Nyamweya, Sisia, \& George, 2014). In 2002, Malawi officially introduced its poverty strategy paper. Similarly, Nigeria inaugurated couple of strategies namely: Poverty Alleviation Programme Development Committee in 1994,
National Economic Empowerment Development Strategy between 1997-2007, President Yar'adua between 2007-2010 launched a 7-point agenda for food security and poverty eradication and President Goodluck Jonathan between 20102015 launched the transformation agenda; a five year development plan focused on non-inflationary growth, employment generation and poverty alleviation (Jakonda \& Alexander, 2015). Finally, in 2016 Zimbabwe launched the Interim Poverty Reduction Strategy Paper (Mtomba, 2016)

Despite these tremendous progress that clearly speaks volumes of politicians' intention to reduce poverty as they claimed, about three in five of the world's poor are now living in Africa (Christiansen \& Hill, 2019, 34) Approximately 40 percent of the Saharan Africa (SSA), population still lived in extreme poverty in 2018 (World Bank, 2020, 13). SSA also has the highest rate of multidimensional poverty, with 58 percent of the population considered to be multidimensionally poor (Oxford Poverty \& Human Development Initiative, 2018, 39; Tewolde \& Weldeyohannes, 2018, 474).

Of course, researchers have documented multiple causes that explain the reasons for the persistence of poverty in Africa. Unfortunately, this paper is not about these documented reasons that are genuine. It looks at another different reason that could also be genuine. It does so by interrogating the inextricable nexus between poverty and politicians in Africa. In other words, this paper meticulously proffers the argument that the main reason why Africa despite all of the inauguration of poverty reduction strategies cannot substantially reduce poverty is simply because it is strategic to the selfish interest of politicians.

Structurally, this paper is divided into two segments. The first segment begins with a conceptual clarification of politician and discussion on how poverty can be defined and measured, and quantification of its prevalence in Africa. And finally, the second segment explains the inextricable nexus between poverty and politicians, and then concludes the paper.

\section{CONCEPTUAL CLARIFICATION OF POLITICIANS}

Gaines, Miller, Larry, and Roger LeRoy (2012) narrowly conceptualized politicians as elected representatives. From political science perspective, elected representatives are members of parliament, legislature, national assembly that represent the interest of their constituents that elected them. Politician is also defined as a person holding or seeking an elected seat in government. An elected seat in government 
mainly speaks to the president and prime minister depending on the organic law of the state or country.

The above definitions of politician fits into African politics. They are mainly from the first branch of government known as Legislature, Parliament, National Assembly, and the Executive headed by the president and prime minister. They may not necessarily be career politicians or political careerists conceptualized by (Mattozzi and Merlo, 2008). The legislators or parliamentarians have an important role to play in enacting good laws that can lead to poverty reduction and the attainment of sustainable democracy in Africa and elsewhere. As a matter of fact, parliament is by law responsible to give effect to poverty reduction strategy introduced by the executive. By concurrent vote, the strategy becomes the blue print or roadmap for national development. For example, the poverty reduction strategy of Liberia was approved in 2008 by the National Legislature.

According to the constitutions of most countries in Africa, the legislature is the representative institution which is charged with holding the executive accountable for achieving the objectives set forth in the PRSP; this mandate typically allows legislatures to represent the aspiration, wishes, and concerns of their constituents to the government and mediate between them. Legislatures in most countries also have the constitutional right to oversee national budgets reviewing whether the government's allocation of resources is consistent with their constituents' demands as well as with the country's developmental objectives, scrutinizing government expenditures and revenues (including loans and credits from the international institutions), ensuring that money is being allocated to programs that have won legislative approval, and identifying instances of financial dishonesty and irregularity.

At the time of seeking seats or political power, these politicians were elected on the basis of their campaign promises or manifestos that focus on poverty reduction. Put in other words, during elections campaign, political aspirants made promises of using the law to improve the livelihood of electorates.

\section{DEFINING AND MEASURING POVERTY}

Before interrogating the inextricable nexus between poverty and politicians in Africa as the crux of this paper, it is important to understand how poverty is commonly defined and measured. For this purpose of this paper, the United Nations and the World Bank concept or definition widely accepted as international standard for all countries in the world in which Africa is no exception is used as the working definition. The intention is not to intellectualize the definition of poverty. But to rather still on the surface.

Precisely, this paper narrows the definition to economic poverty, which is usually measured in terms of material living standards. The most common measures are Gross Domestic Product (GDP), per capita and the number or share of people living under the poverty line.
According to the World Bank, a country's wealth is measured in terms of GDP, which is the total value added to all goods and services produced in a national economy per year. Because the size of any country's economy is related to the number of inhabitants, GDP is commonly divided by total population to obtain GDP per capita. This measure allows us to compare income levels across countries and to compute income growth over time. The World Bank classifies economies into four income groups: lower income (up to US\$ 1,005), lower-middle income (US\$ 1,006 - 3,955), uppermiddle income (US\$ 3,956 - 12,235), and higher income (US\$ 12,236 and above) (these are official standards for Gross National Income in 2018). As of June 2020, majority of the countries in SSA were classified as low income (World Bank List of Economies, 2020). Arguably, this ranking suggests the extremity of poverty in these countries despite the existence of poverty reduction strategies.

According to the World Bank, if you're living on \$1.90 a day or less, you're living in extreme poverty. Millions of the extremely poor live in the world's low-income countries characterize by low quality housing, not enough money for school fees (primary education isn't always free), health-care expenses, and not be enough to purchase nutritious food or to stave off hunger.

In summary, the World Bank describes poverty in this way:

"Poverty is hunger. Poverty is lack of shelter. Poverty is being sick and not being able to see a doctor. Poverty is not having access to school and not knowing how to read. Poverty is not having a job, is fear for the future, living one day at a time.

Poverty has many faces, changing from place to place and across time, and has been described in many ways. Most often, poverty is a situation people want to escape. So poverty is a call to action for the poor and the wealthy alike a call to change the world so that many more may have enough to eat, adequate shelter, access to education and health, protection from violence, and a voice in what happens in their communities."

In addition to a lack of money, poverty is about not being able to participate in recreational activities; not being able to send children on a day trip with their schoolmates or to a birthday party; not being able to pay for medications for an illness. These are all costs of being poor. Those people who are barely able to pay for food and shelter simply can't consider these other expenses. When people are excluded within a society, when they are not well educated and when they have a higher incidence of illness, there are negative consequences for society.

\section{QUANTIFYING POVERTY IN AFRICA}

The essence for this sub topic is to connect the World Bank definition to poverty in Africa. By doing so, this article employ fresh data to quantify poverty in Africa. 
About three in five of the world's poor are now living in Africa (see Christiaensen \& Hill, 2019, 34). The depth of poverty in Africa is also more extreme. For those living below the poverty line in Africa, the average consumption level is only US $\$ .70$ a day, considerably lower than levels in other regions that are all nearly approaching the $\$ 1$ a day level (Bhorat et al., 2016, 10).

Approximately 40 percent of the SSA population still lived in extreme poverty in 2018 (World Bank, 2020, 13). SSA also has the highest rate of multidimensional poverty, with 58 percent of the population considered to be multidimensionally poor (see Oxford Poverty \& Human Development Initiative, 2018, 39; Tewolde \& Weldeyohannes, 2018, 474).

Poverty rates are highest in the Sahel countries and the northern regions of the coastal West African countries, extending east into Ethiopia and southeast into the Congo Basin and its eastern surrounding regions in Burundi, Rwanda, Tanzania, and Uganda (Christiaensen \& Hill, 2019)

Another recently published scenario analysis (October 2020) of the impact of COVID-19 in Africa finds that relative to the pre-COVID-19 Reference (or baseline) forecast, 14 million additional Africans will be extremely poor in 2020.

It is widely recognized that climate change will disproportionately affect poorer countries, and poorer individuals within countries, with Africa identified as the region most vulnerable to the impacts of climate change (Jafino et al., 2020; Serdeczny et al., 2017). Sub-Saharan Africa is the region where climate change is expected to push the most people into poverty. Under high climate change scenarios, under which there are greater impacts of climate change, the numbers of people pushed into extreme poverty in SSA are 39.7 million (Jafino et al., 2020),

Similarly, according to (Patel, 2018), twenty-seven of the world's 28 poorest countries are in Sub-Saharan Africa. Each of these countries has a poverty rate of over 30 percent. The research further establishes or reveals that while the absolute number of people living in global poverty has decreased over the last several decades, in Sub-Saharan Africa, the number has increased, and substantially so.

As a way of corroborating the above empirical data, it is interesting to know that the World Bank. 2020. Poverty and Shared Prosperity 2020: Reversals of Fortune provides new evidence on emerging "hot spots," where multiple threats to poor people's lives and livelihoods converge. Many of these hot spots are in Sub-Saharan Africa, a region now expected to be home to about a third of the people who are newly impoverished by COVID-19.

Any attempt to question the veracity of the above empirical data on the premise that statistics is not an exact science, it will not still deny the fact of the wide spread or prevalence of extreme poverty in Africa, especially SSA.
The Inextricable nexus between Poverty and Politicians in Africa

The crux of this paper is premise on the notion that the prevalence of extreme poverty in Africa is strategic to the self-interest of politicians. In other words, extreme poverty in Africa seems to be a perpetual phenomenon because it serves the interest of politicians. Financial manipulation for vote buying is the interest that explains the link or nexus between the former and the latter in Africa. As interest to politicians, it is important to provide at least a brief understanding of vote buying.

In the words of (Stokes, 2007a; Hicken, 2011; Linos, 2013; Robinson and Verdier, 2013), vote buying is a particular form of political clientelism, i.e. the direct exchange at the individual level of rewards and material goods by political patrons in return for electoral support by voters. For their part, (Onuoha \& Ojo, 2018) conceptualized vote buying as 'any form of financial, material or promissory inducement or reward by a candidate, political party, agent or supporter to influence a voter to cast his or her vote or even abstain from doing so in order to enhance the chances of a particular contestant to win an election'. Similarly, Schaffer and Schedler (2005) conceptualized vote buying in its literal sense, as a simple economic exchange. They argued that candidates "buy" and citizens "sell" votes, as they buy and sell apples, shoes or television sets. He adds that the act of vote buying is a contract, or perhaps an auction, in which voters sell their votes to the highest bidder.

A careful analysis of all of these likeminded definitions of vote buying points to two fundamental theoretical questions. Who are the sellers? And why are they selling their votes? (Stokes, 2005, 2007a, 2007b; Blaydes, 2006) eloquently theorized the relationship between poverty and vote buying that answer these questions. They argued that poverty in particular has been emphasized as an important source of vote buying that enables political parties to exploit the

material needs of deprived voter groups by trading rewards for votes. From their theory, it can be inferred without doubt that politicians who engage in vote buying systematically and consiciously target specific groups during elections based on their socio-economic characteristics.

In African politics or elections, observation indisputably established that these specific group with socio-economic characteristics are people walloping in extreme poverty that careless about serious implications of selling their votes. Their vulnerability to financial manipulation stems from poverty. They are the very people in majority, mostly the youths that the same bidders (politicians) promised to jerk out of the dungeon of poverty. Because of their socio-economic conditions, these poor voters are unlikely to resist the temptations of vote-buying during elections in Africa. In the worlds of Michael Jobbins, Director of global affairs and partnerships at Search for Common Ground, a Washingtonbased nongovernmental organization working on conflict 
resolution around the world, they are the young who are out there dying in the streets, clashing with other young people to advance the interests of the older generation."

In African politics, it can be argued that vote buying manifests mainly in two common forms. Trucking of the specific target groups from their original place of voting to another locality that they know little or nothing about. Before their departure, they are briefed about incentives, issued T-shirt, cap of the bidder, specific amount of money very insignificant to reducing their poverty status, and accommodation. Second, voters are financially induced coupled with food, drinks, the bidder T-shirt, face caps, etc. to cast their ballot paper in favor of the bidders in their legal place of voting. Supportive to my assertion, Michael Jobbins asserts "for young people who do not have meaningful ways to participate in politics on their own behalf, such as through youth movements and organizations, they may see their only role in a process dominated by older generations as "agents rallying people up in the streets for a little bit of cash."

In some instances, voters are promised cash in return if they produce pictorial evidence of the ballot cast in favor of the bidders. Although it is prohibited by election laws to carry smart phone or any gadget into the voting booth. However, voters clandestinely take advantage of poor monitoring and supervision.

In order to support the argument or claim, it is imperative to cite some realistic examples or instances of vote buying.

In 2013, The Kenyan Human Rights Commission (KHRC) released video of two prominent Kenyan politicians engaging vote buying; Ferdinand Waititu, the controversial and now former Member of Parliament from Nairobi's urban Embakasi Constituency and James Ongware, a candidate for governor of Western Kenya's predominantly rural Kisii County (Kramon, (2013. According to (Al Jazeera, 2013), at the end of the video, Waititu personally handed out cash to a number of people in the crowd.

As he does so, the crowd rushes forward and he instructed those who have received the cash to share it with others in the crowd. As for Ongware, the video showed an orderly system of cash distribution to potential voters at a rally in Kisii. Ongware's agents first created lines of men, women, and youth and subsequently handed out cash to them as they wait, (Kramon, 2013)

Anecdotal evidence suggests that vote buying is widespread during election campaigns in Nigeria. For example, during the All Progressive Congress (APC) presidential primary in Lagos State before the 2015 elections, it was reported that "over 8 000 delegates who participated allegedly made US\$5 000 each from the candidates. Delegates were supposed to have received US\$2 000 each from the Atiku Abubakar group and also US\$3 000 each from the Buhari group. Given that more than 8000 delegates were reported to have attended the primaries, the competing camps could have spent more than
US\$16 million and US\$24 million respectively on vote buying at the primary stage" (Tribune, 2018). Similarly, in the 28 September 2016 gubernatorial election in Edo, observers reported massive vote buying by the two main political parties, the APC and the People's Democratic Party (PDP). The parties were accused of giving N3 000 to N4 000 for votes in several polling units, (The Whistler, 2016). In Sao Tome and Principe, the exchange of cash for votes has been a rampant phenomenon, (Vicente \& Wantchekon). (Kramon and Posner, 2013) argued that cash and other types of handouts, which are often referred to as "chop money", are common to political campaigns in Ghana.

In February 2017, Plain clothes officers of the Liberia National Police (LNP) arrested Stephen Cooper age 33; Raymond Bartee age 20; and Christian Bartee age 19; in connections to buying voter cards near the Susan Berry Registration Center in Congo Town. One of the accused was arrested with as sixteen newly-registered voter cards to several individuals, (Sieh, 2017) below is pictorial proof.

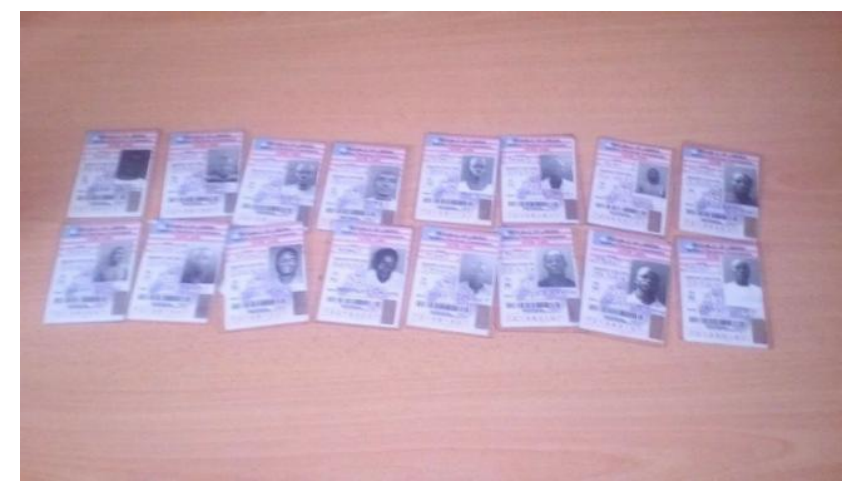

Courtesy of front page Africa, 2017

In 2017, Helene Cooper from the New York Times outlined what seem to be

instances of vote buying gathered from field experience during October 2017 elections. Considered as anecdotal evidence suggesting the widespread of the former, here are few instances that worth mentioning in this article.

On Liberian social media of cash-for-votes videos, a woman wearing a "Charles Brumskine for President" $T$-shirt and a handbag around her neck and angrily announcing that she had not been given the 500 Liberian dollars (\$4.50) that she had been promised for showing up at a Brumskine rally.

On the same Liberian social media of cash-for-votes videos, presidential candidate Oscar Cooper was videotaped standing in a doorway handing out cash to Liberians.

A woman known as Mother Comfort Lloyd and her 30 helpers have prepared rice, spicy peppery soup and potato greens to hand out to supporters at Mr. Weah's headquarters in the Monrovia neighborhood called Fish Market. Around 3:30 in the afternoon, the line forms and snakes through the grounds. 
Princess Gray, age 32 who voted for Mr. Weah for president in last election decided to vote Mr. Alexander B. Cummings Jr., the former Coca-Cola executive of the Alternative National Congress made this comment that suggest vote buying. "He gave my two sons 14,000 dollars for scholarships," she said. That's the equivalent of \$120, for her 8-year-old twins, Prince and Princeton, both secondgraders, to go to school". Jacob Wuray, age 23, of Congo Town, said he came every day to eat. When the legislative candidates show up in their big cars to hand out cash, he is there to receive his 250 Liberian dollars (around \$2.25).

From the definitions and instances or realistic examples mentioned so far, it worth asking this logical and reciprocal question. How it is possible for politicians in Africa to reduce extreme poverty when it is strategic to their political interest? Reducing poverty substantially will simply mean reducing the chances for vote buying. So, how is this reciprocal relationship possible?

Reciprocally, reducing extreme poverty substantially will mean the same for education. Now, education also brings about enlightenment and empowerment. Arguably, when people are empowered from enlightenment, they are able to make informed decision. Moreover, it reduces the vulnerability of being manipulated financially especially for a petit cash or pocket change that is highly insignificant to reducing or improving their poverty status. No doubt, politicians in Africa are aware of this. More importantly, majority of the electorates in Africa are poverty-stricken youths prone to manipulation. And because these povertystricken youths promote their individual political agenda, politicians are not doing much to tackle poverty. They see the situation as their greatest political weapon to advance their interest. In other words, the limitation of the youths that constitute majority of the electorates in Africa due to extreme poverty and unemployment operates in the interest of politicians. When it comes to election violence that advance the personal agenda of politicians, they rely on vulnerable youths. So, if politicians tackle this vulnerability, how can they manipulate the youth to engage in election violence? Interestingly, Hueta (2015) electoral blackmail theory supports the argument. He opines that electoral losers challenge electoral results to strengthen their own capacity for negotiation with the newly elected government. Hueta further argues that losing political forces, in exchange for conceding defeat, are interested in: reforming the electoral process; legislating key issues to further their parties' agendas; getting pork barrel; filling committee chairs in congress/parliament in order to gain influence over the legislative process; obtaining cabinet positions; appointing members of their party as judges; and so on.

This is why this article argues that if politicians really wanted to reduce poverty in Africa substantially, they would have by now scored significant marks. But the truth is they will not. Their fear of losing political relevance because of failed promises will continue to keep Africa on top of the list of continent with the largest number of people living in extreme poverty despites decades of implementing poverty reduction strategies.

\section{CONCLUSION}

This article reliance on anecdotal evidence to support the arguments advanced in this paper does not in any dismiss or invalidate the reality of vote buying serving the selfish interest of politicians in Africa. The truth of the matter is vote buying has become part of the embodiment of the political culture of Africa.

It is now time for electorates to understand the politics of poverty that has been a mere rhetoric. For more than a decade politicians continue to fight extreme poverty in Africa but cannot score substantial marks. Evidently, politicians in other Countries from different Continents have scored significant marks in the reduction of extreme poverty than Africa. It will surprise you to know that some of these Countries such as Singapore, China, Latin America, etc. that are not endowed with the kind of natural resources strategic to poverty reduction in Africa are far ahead of poverty reduction scores.

To solve this aged problem, civil society must rollout their sleeves to robustly engage electorates through the concept of sustain civic education for holding politicians accountable for their failures or pretense of reducing extreme poverty substantially.

\section{REFERENCES}

[1] Al Jazeera (2013) Videos expose Kenya's cash-for-votes scandal https://www.aljazeera.com/news/2013/3/1/videos-expose-kenyacash-for-votes-scandal Accessed 3 September 2021

[2] Bhorat, H., Cassim, A., Ewinyu, A. \& Steenkamp, F. (2016). Social Protection and Inequality in Africa: Exploring the interactions. In eds. A. Odusola, G.A. Cornia, H. Bhorat, \& P. Conceição. Income Inequality Trends in sub-Saharan Africa. Divergence, Determinants and Consequences. New York: Regional Bureau for Africa, UNDP, 179-202. https://www.africa.undp.org/content/rba/en/home/library/reports/i ncome-inequality-trends-in-subsaharan-africa--divergence-dete.html Accessed 29 August 2021

[3] Canagarajah, S., and Van Diesen, A., (2006), 'The Poverty Reduction Strategy Approach Six Years On: An Examination of Principles and Practice in Uganda' Development Policy Review, 24 (6), pp. 647-667

[4] Christiaensen, L. \& Hill, $\boldsymbol{R}$. (2019) Poverty in Africa. In eds. K. Beegle \& L. Christiaensen. Accelerating poverty reduction in Africa. Washington, DC: The World Bank. 33-50. https://openknowledge.worldbank.org/handle/10986/32354 Accessed 29 August 2021

[5] Gaines, Miller, Larry, Roger LeRoy (2012). Criminal Justice in Action. Wadsworth Publishing. p. 152. ISBN 978-1111835576.

[6] Grant, Grant, Donald Lee, Jonathan (2001). The Way It Was in the South: The Black Experience in Georgia. University of Georgia Press. p. 449. ISBN 978-0820323299. Accessed 24 August 2021

[7] Jakonda, Agara, Jummai \& Alexander, Pojwan, Martina (2015) Eradicating Extreme Poverty in Nigeria: An Appraisal of Millennium Development Goal One (MDG 1) https://iiardpub.org/get/IJEBM/VOL\%201/46-54.pdf Accessed 29 August 2021

[8] Jafino, B. A., Walsh, B., Rozenberg, J., \& Hallegatte, S. (2020) Revised Estimates of the Impact of Climate Change on Extreme 
Poverty by 2030 . Policy research working paper. Washington, DC: World Bank.

https://openknowledge.worldbank.org/bitstream/handle/10986/345 55/Revised-Estimates-of-theImpact-of-Climate-Change-onExtreme-Poverty-by-2030.pdf?sequence=1\&isAllowed=y Accessed 28 August 2021

[9] Kramon, E., \& Posner, D. N. (2013). Who benefits from distributive politics? How the outcomes one studies affect the answers one gets. Perspectives on Politics, 11(2), 461-474. Accessed 2 September 2021

[10] Kramon, E. (2009). Vote-buying and political behaviour: Estimating and explaining vote-buying's effect on turnout in Kenya. Working Paper Number 114, Afro Barometer

[11] Mtomba, Victoria (2016) \$2,7bn poverty reduction strategy for Zimbabwe launchedhttps://www.tralac.org/news/article/10554-27bn-poverty-reduction-strategy-for-zimbabwe-launched.html accessed 29 August 2021

[12] Multidimensional_Poverty_Index(2018)The_Most_Detailed_Pict ure_To_Date_of_the_World's_Poorest_People/links/5c3f234d 458 515a4c72a674b/Global-Multidimensional-Poverty-Index-2018The-Most-Detailed-Picture-To-Date-of-the-Worlds-PoorestPeople.pdf Accessed 29 August 2021

[13] Mattozzi, Andrea and Merlo, Antonio (2008) "Political careers or career politicians." Journal of Public Economics 92\#3: 597-608.

[14] Nyamboga, Nyamweya, Sisia, \& George, (2014) The effectiveness of Poverty Reduction efforts in Kenya: An evaluation of Kenyan Government's policy initiatives on poverty alleviation https://core.ac.uk/download/pdf/234670617.pdf Accessed 29 August 2021

[15] Onuoha, Freedom and Ojo, Jide (2018) Practice and Perils of Vote Buying in Nigeria's Recent Elections. https://www.accord.org.za/conflict-trends/practice-and-perils-ofvote-buying-in-nigerias-recent-elections/ Accessed 4 September 2021

[16] Oxford Poverty \& Human Development Initiative. (2018). Global Multidimensional Poverty Index 2018: The most detailed picture to date of the world's poorestpeople.UniversityofOxford.https://www.researchgate.net/pr ofile/Frank_Vollmer2/publication/330421754_Global_Multidimen sional_Poverty_Index_2018_The_Most_Detailed_Picture_To_Dat e_of_the_World's_Poorest_People/links/5c3f234d458515a4c72a6 74b/Global-Multidimensional-Poverty-Index-2018-The-MostDetailed-Picture-To-Date-of-the-Worlds-Poorest-People.pdf Accessed 29 August 2021

[17] Patel, Nirav. (2018) "Figure of the Week: Understanding Poverty in Africa." Brookings, Brookings, 21 Nov. 2018, www.brookings.edu/blog/africa-in-focus/2018/11/21/figure-ofthe-week-understanding-poverty-in-africa/. Accessed 1 September 2021

[18] Serdeczny, O., Adams, S., Baarsch, F., Coumou, D., Robinson, A., Hare, W. \& Reinhardt, J. (2017). Climate change impacts in Sub-Saharan Africa: from physical changes to their social repercussions. Regional Environmental Change, 17(6), 1585-1600. https://link.springer.com/article/10.1007/s10113-015-0910-2 Accessed 30 August 2021

[19] Sieh, Rodney (2017) Poverty-Stricken Voters Selling Voter Cards in Liberia - Three Busted, https://frontpageafricaonline.com/politics/breaking-news-povertystricken-voters-selling-voter-cards-in-liberia-3-busted/ accessed 18 September 2021

[20] Stokes, S. C. (2007). Political clientelism. In C. Boix and S Stokes (Eds.) Handbook of comparative politics. Oxford: Oxford University Press

[21] The Whistler (2016) Edo Decides: APC, PDP in Vote Buying, Interstate Travelers Trapped, $<$ https://thewhistler.ng/story/edodecides-apc-pdp-in-vote-buyinginterstate-travelers-trapped/Accessed 6 September 2021

[22] Tribune, (2018) Overcoming Vote Buying, Available at:htp://www.tribuneonlineng.com/overcoming-vote-buying/ Accessed 6 September 2021
[23] Tewolde, M. and Weldeyohannes, M. (2018). Drivers of poverty in Sub-Saharan Africa: Policy implications for achieving Agenda 2030 for Sustainable Development. International Journal of Scientific and Research Publications, Volume 8, Issue 12, 473486.http://dx.doi.org/10.29322/IJSRP.8.12.2018.p8462 Accessed 30 August 2021

[24] World Bank List of Economies, (2020). https://www.acpeaccredit.org/pdf/ISP/WorldBankData-CountryClassifications.pdf Accessed 30 August 2021

[25] World Bank (2020). Reversals of fortune. Poverty and shared prosperity 2020.

[26] Washington, DC: The World Bank.https://openknowledge.worldbank.org/bitstream/handle/1098 6/34496/9781464816024.pdf accessed 30 August 2021

[27] World Bank. (2020(. Poverty and Shared Prosperity 2020: Reversals of Fortune. Washington, DC: World Bank. doi: 10.1596/978-1-4648-1602-4. License: Creative Commons $\begin{array}{lllll}\text { Attribution } & \text { CC } & \text { BY } & 3.0 & \text { IGO }\end{array}$ https://openknowledge.worldbank.org/bitstream/handle/10986/344 96/9781464816024.pdf Accessed 1 September 2021

[28] VOA (2009) Liberia's President Sirleaf Launches Poverty Reduction Program https://www.voanews.com/archive/liberiaspresident-sirleaf-launches-poverty-reduction-program Accessed 29 August 2021

\section{ABOUT THE AUTHOR}

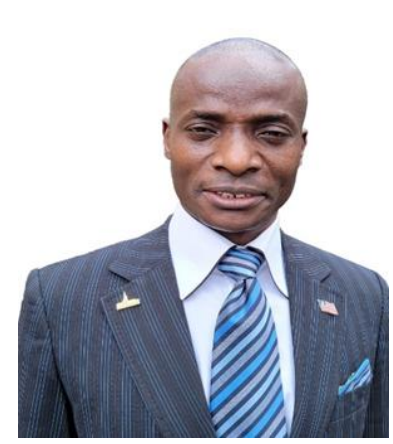

Ambrues Monboe Nebo Sr. is a lecturer in the Department of Political Science, University of Liberia. Department of Sociology, African Methodist Episcopal University, Criminal Justice Department, Adventist University of West Africa, Liberia and $\mathrm{He}$ has been a classroom lecturer since 2016. Currently, he is the Vice President for Administration, Hill City University of Science and Technology-Liberia. He has completed all academic requirements for Doctorate of Sociology (D.Sc.) with a GPA of 4.00 (Summa Cum Laude) at the Atlantic International University (AIU). He holds $\mathrm{MSc}$ in the top $5 \%$ of the graduating Class in Peace and Conflict Studies with emphasis in Humanitarian and Refugee Studies form University of Ibadan, Nigeria, Post Graduate Certificate with distinction in Public Administration from Ghana Institute of Management and Public Administration Ghana, Bachelor of Arts (Magna Cum Laude) in Sociology from African Methodist Episcopal Zion University College in Liberia, a graduate of Liberia National Police Academy and Training School formerly National Police Training Academy and obtained various Certificates in peacekeeping operations from the Kofi Anna International Peacekeeping Training Centre in Ghana.

Professionally, he is a senior police officer of the Liberia National Police with fifteen years of experience in Training and Administration.

He is the author of three books namely: 'The Politicization of the Criminal Justice System: A Liberian Perspective' available at 
https://www.amazon.com/Politicization-Criminal-JusticeSystem-Socio-Political/dp/6139445337 and Morebooks shop. The Wave of Protests Leading to Regimes Change in Africa: A Sociological Perspective available

at
https://www.amazon.co.uk/dp/9975153461

and Introduction to Liberia Criminal Justice System: A

Concise

Edition

available https://www.morebooks.de/store/us/book/introduction-to-

liberia-criminal-justice-system/isbn/978-620-3-04123-1

Moreover, he has authored a dozens of articles dealing with contemporary issues in Africa and Liberia that can be accessed online at

https://neboambrues.academia.edu/ 